SCJR 15, no. 1 (2020): 1-20

\title{
Jewish Universalism?: The Nations in the Rosh Hashanah Liturgy ${ }^{1}$
}

\author{
RUTH LANGER \\ ruth.langer@bc.edu \\ Boston College, Chestnut Hill, MA 02467
}

In its December 2015 document "Gifts and Calling,"2 reflecting on the fiftieth anniversary of Nostra Aetate 4, the Vatican's Commission for Religious Relations with the Jews affirms that the Church, through the New Covenant, fulfills the universal aspect of God's initial call to Abraham; this, in turn, makes the Church dependent on Israel. The document then continues by expressing the hope that Jews might reciprocate this understanding, wishing that "Jews could with regard to the Abrahamic covenant arrive at the insight that Israel without the Church would be in danger of remaining too particularist and of failing to grasp the universality of its experience of God" (33). Following Cardinals Kasper and Koch, upon whose language it draws, ${ }^{3}$ this document here throws down two gauntlets: that Jews need to articulate a specific positive relationship with Christianity; and that this relationship should challenge Jews to abandon at least some of their particularism and refocus on the universalist aspects of their tradition.

As a Jewish participant in dialogue, let me state at the outset that I find both challenges troubling. Indeed the specter that theological dialogue would result in Christian demands that Jews adapt their theology led Rabbi Joseph B. Soloveitchik,

\footnotetext{
${ }^{1}$ The original version of this paper was developed for the conference, "Fulfilling the Promise of a New Relationship: An Academic Roundtable on Christian-Jewish Relations," sponsored by the Institute for Catholic-Jewish Relations, St. Joseph's University, January 7-10, 2019. It was also shared at the Comparative Theology Colloquium at Boston College that spring. I am grateful for the comments received in both contexts and the comments of the reviewers for SCJR.

2 “"The Gifts and the Calling of God Are Irrevocable' (Rom 11:29): A Reflection on Theological Questions Pertaining to Catholic-Jewish Relations on the Occasion of the 50th Anniversary of Nostra Aetate (No. 4)."

https://www.ccjr.us/dialogika-resources/documents-and-statements/roman-catholic/vatican-curia/crrj$2015 \operatorname{dec} 10$

Compare $\S 13$, "Without her Jewish roots the Church would be in danger of losing its soteriological anchoring in salvation history and would slide into an ultimately unhistorical Gnosis."

${ }^{3}$ See Philip A. Cunningham, "The Sources behind " "The Gifts and the Calling of God Are Irrevocable" (Rom 11:29): A Reflection on Theological Questions Pertaining to Catholic - Jewish Relations on the Occasion of the $50^{\text {th }}$ Anniversary of Nostra Aetate (No. 4), ' Commission of the Holy See for Religious Relations with the Jews, December 10, 2015," Studies in Christian-Jewish Relations 12 (2017): 8, nn. 12-13. https://doi.org/10.6017/scjr.v12i1.9792.
} 
familiar with the drafts of Nostra Aetate, to deliver his famous 1964 speech "Confrontation," severely limiting modern orthodox participation in such discussions. ${ }^{4}$ However, the questions posed here are worthy of a more in-depth study. How do Jews today think about their relationship to the non-Jewish world, especially to Christianity? This article will not attempt a comprehensive answer, but will instead focus on how American Jews are taught to address it through their liturgical texts. It takes as its data set the commentaries printed in recent and widely used American liturgies for the fall "High Holy Days," Rosh Hashanah (the New Year) and Yom Kippur (the Day of Atonement), both days of unusually high synagogue attendance. There are explicitly universalist themes in the liturgy for these days, especially on Rosh Hashanah. Focusing on specific prayers that express a tension between universalism and particularism, I will demonstrate that while Jewish tradition was significantly particularist, contemporary liturgies, to different degrees, but across most of the spectrum of American Jewish practice, deliberately emphasize a universalist vision.

\section{Universalism and Particularism as Theological Categories}

Is this contrast between Jewish particularism and Christian universalism a stereotype, or is there substance to it? Malka Z. Simkovich demonstrates that even in the pre-Christian period, it is overly simplistic. Within the diversity of biblical prophetic literature exists not only particularist understandings of Jews and non-Jews but also expectations that non-Jews may, in eschatological times, come to worship God. She demonstrates that as the Second Temple period progresses, such universalist views become more and more common, with some accepting and valuing gentile worship of God not only in the future but also in the present. Much of this, she says, reflects the socio-cultural realities of the worlds in which Jews were living, and the shifting needs to construct higher or lower barriers between communities. In the aftermath of the failure of the Jewish revolts against Rome, the more universalist views diminished significantly, likely due to the need to preserve communal identity in a situation of increased oppression. ${ }^{5}$

As Simkovich demonstrates throughout her book, "universalism" and "particularism" are labels that apply to a diversity of views, even within Second Templeera Judaism. Her initial working definition of universalism is helpful, though. She says, "Universalist literature presumes that all people, regardless of religion, have access to a relationship with the Israelite God and the benefits which He promises to those loyal to Him, without demanding that they convert or participate in the

\footnotetext{
${ }^{4}$ Delivered at St. John's Seminary, Brighton, Massachusetts and subsequently published with the Rabbinic Council of America's resolution summarizing it in Tradition 6:2 (1964): 5-29. See especially II.3., 21-25.

${ }^{5}$ Malka Z. Simkovich, The Making of Jewish Universalism from Exile to Alexandria (Lanham. MD: Lexington Books, 2017), passim, summarized in Part IV, 139-143. Relevant to a broader discussion is the construction of the categories of Jew and gentile. See Adi Ophir and Ishay Rosen-Zvi, Goy: Israel's Multiple Others and the Birth of the Gentile (Oxford: Oxford University Press, 2018).
} 
Israelite community as a Jew." ${ }^{16}$ By contrast, a particularist understanding expects that the nations need to become part of Israel to benefit from a relationship with God. ${ }^{7}$

How do these understandings intersect with others' categories of theologies of religions? The most comprehensive and deliberate Jewish discussion of the topic appears in Alan Brill's Judaism and Other Religions, where he discusses and defines four different categories: exclusivism, pluralism, inclusivism, and universalism. . "Particularism" does not appear on his list. Still, his discussions of exclusivism, the understanding that one's religion is the only true one, ${ }^{9}$ suggest that these two categories are substantially identical. Brill defines "universalism" as representing an understanding that there is a single universal truth, located in or communicated by God, made known to all humanity. Brill observes, "This category does not exist in the standard Christian typology since historically they required salvation through Christ," causing universalist theologies of the truth of other religions to be subject to suspicion. Christians today favor inclusivist theologies, he says, which acknowledge truth in other religions but see Christian comprehension as superior. ${ }^{10}$

Consistent with his observations, Catherine Cornille's overview of these categories in (Christian) Comparative Theology initially lists the "three classical paradigms": exclusivism, inclusivism, and pluralism. ${ }^{11}$ However, she quickly expands beyond them. After her discussion of exclusivism, she devotes a section to particularism as an emerging paradigm by which one employs the epistemology of one's religious tradition to evaluate and constructively learn from others. ${ }^{12}$ Nevertheless, this is not what "Gifts and Calling" means by particularism (see below). Cornille also never names universalism as a category. It is perhaps possible that we come closest to "universalism" through her "open inclusivism," which recognizes the potential of truth "in any teachings or practices that are not in contradiction with one's own tradition." This point means that one can discover new truths through the encounter with the other. ${ }^{13}$ However, this is not precisely "universalism" because the truth of one's own tradition remains an absolute criterion.

Neither Simkovich, Brill, nor Cornille offer schemas that fit the Vatican document's gauntlet. Both of the last two presidents of the Council for Religious Relations with the Jews, Cardinals Walter Kasper and Kurt Koch, employed this dialectic of universalism and particularism. ${ }^{14}$ Still, it seems, they employ the terms

\footnotetext{
${ }^{6}$ Simkovich, xviii.

${ }^{7}$ She explores these in Chapter 1.

${ }^{8}$ Judaism and Other Religions: Models of Understanding (New York, NY: Palgrave Macmillan, 2010), Chapter 2, "Theological Categories." His list first appears on pp. 16-17, but subsequently receives detailed discussion and refinement.

${ }^{9}$ Brill, 16, 19-21, 23.

${ }^{10}$ Brill, 17, 18, 23.

${ }^{11}$ Meaning and Method in Comparative Theology (Hoboken, NJ: John Wiley and Sons, 2020), Ch. 2,

"The Status of Other Religions in Comparative Theology," here p. 44.

${ }^{12}$ Cornille, 2.2, "Particularism and Comparative Theology."

${ }^{13}$ Cornille, 2.4 , p. 58.

${ }^{14}$ See note 3 above.
} 
less as precise theological paradigms than as descriptive historical categories. They couch their discussion in terms of the Abrahamic covenant and of God's abstract imperative that Abraham "be a blessing...through [whom] all the families of the earth will be blessed" (Gen 12:2-3). ${ }^{15}$ By spreading God's word and blessing to all the nations, the Church is universalist. In being concerned about herself and not the nations (and not the Church), Israel is particularist. The Church actively seeks to be a blessing to the world; Israel understands her very presence to be that blessing and, at best, understands her role to be a passive one. In other words, Kasper and Koch's universalist/particularist contrast verges on a moral judgment that claims, "The Church is generous; Israel is selfish - but should not be because she too participates in the Abrahamic covenant." 16 In neither case are these categories expressing theological understandings about the truth of other religion's teachings. This point is more a discussion of spreading the Abrahamic truth.

"Gifts and Calling" does not call on Israel to abandon all particularism, but instead calls out the danger of being "too particularist." Jewish political theorist Michael Walzer distinguishes between a universalism that insists that all become part of its own path - certainly the traditional Christian understanding and the one with which "Gifts and Calling" still struggles - and a universalism that recognizes multiplicity yet allows a particular concern for one's own group. There is thus a universalism, he says, that "is grounded in a particularity that recognizes the legitimacy of other particularities." ${ }^{17}$ While both paths have biblical roots, he suggests that the second is more characteristic of Judaism.

If universalism and particularism are descriptive historical categories of a group's horizon of concern, then the first task is to assess whether Jews today are indeed characterized by a particularism that limits or excludes the universal horizon. Simkovich established that universal Jewish voices are numerous in the preserved literature of the Second Temple period, but notes that these universalist voices disappear as Roman oppression grows after 135 CE. ${ }^{18}$ Perhaps the stereotype of Jewish particularism does hold over the subsequent two millennia? Elsewhere, I demonstrated that embedded in the prophetic voices chosen for the

\footnotetext{
${ }^{15}$ Translation mine. Compare Gen 18:18 and 28:14 which also use the passive form of "bless;" but contrast 22:18 and 26:4's reflexive form. In the latter, the nations are blessing themselves. Acts 3:25 and Gal 3:8 understand the verb to be passive. See the commentary to Gen 12:3 in the Catholic Study Bible, ed. Donald Senior et al. (Oxford: Oxford University Press, 2011), 28.

${ }^{16}$ If this reading is correct, it at least avoids asserting a replacement theology. Important to this dynamic is that once the Church became politically dominant, it became dangerous and often illegal for Jews to proselytize. See, among the copious literature on this topic, David Novak, "Proselytism in Judaism," in Sharing the Book: Religious Perspectives on the Rights and Wrongs of Proselytizing, ed. John Witte and Richard Martin (Maryknoll, NY, 1999), 17-44; Louis H. Feldman, Jew and Gentile in the Ancient World: Attitudes and Interactions from Alexander to Justinian (Princeton, NJ: Princeton University Press, 1993), chs. 9-11.

17 "Nation and Universe," in Thinking Politically: Essays in Political Theory, ed. David Miller (New Haven, CT: Yale University Press, 2007; original publication in The Tanner Lectures on Human Values, Grethe B. Peterson, ed., vol. 11, 507-556 [Salt Lake City: University of Utah Press, 1990]), 184, 188189. Thanks to Shira Wolosky for the reference.

${ }^{18}$ Simkovich, 143.
} 
Jewish lectionary is indeed a subtle expression of Jewish particularism. ${ }^{19}$ However, modern commentators on these haftarot consistently de-emphasize these particularistic elements, suggesting that today's shift in Jewish self-perception and social location generates discomfort with this received expression. These particular commentaries, though, are relatively rare and little consulted.

\section{High Holy Day Liturgies}

In recent years, though, American mahzorim, the prayer books for the High Holy Days, ${ }^{20}$ have included rich sets of commentaries and, among liberal Jews, alternative readings, alongside English translations of the Hebrew prayers. More Jews attend services on these days than any others, the services are particularly spiritually intense and formal, and each attendee has a personal copy of the entire liturgy. Thus, these commentaries can potentially have a significant impact. Because some central received prayers directly raise issues of universalism and particularism, the commentaries on them also provide a wealth of information about what Jewish leaders seek to impart on our topic. ${ }^{21}$

This article primarily considers the commentaries in three liturgies of the 2010s widely used in North America. The Orthodox 2011 Koren Mahzor, with the translation and commentary of Jonathan Sacks, contains an entirely traditional Hebrew text and a literal translation. However, Sacks, himself a leading Orthodox rabbi to the liberal end of the Orthodox spectrum, has been deeply involved in interreligious affairs and has contributed to thinking on our question. His extensive commentary appears on the bottoms of the pages. ${ }^{22}$ The Conservative Movement, in the middle of the American spectrum of forms of Judaism, adheres to the traditional core of the liturgy but is open to creativity around this core. It published its Mahzor Lev Shalem in 2010, complete with literal translations and a commentary consisting significantly of selections from the writings of leading thinkers in the

\footnotetext{
19 "Prophetic Universalism and Particularism in Jewish Liturgy," in Righting Relations After the Holocaust and Vatican II: Essays in Honor of John T. Pawlikowski, OSM, Elena G. Procario-Foley and Robert A. Cathey, eds. (Mahwah, NJ: Stimulus, Paulist Press, 2018), 253-269.

${ }^{20}$ An English term for the early fall (September-October) Ten Days of Penitence from Rosh Hashanah (the New Year, 1-2 Tishrei) to Yom Kippur (the Day of Atonement, 10 Tishrei).

${ }^{21}$ Assessing the commentaries' impact in a scientific way is beyond the scope of this study. I have heard many tell of enhanced personal worship experiences because of the commentaries; some more liberal settings substitute the commentaries for readings on occasion. The nature of the commentaries is also a significant factor in a congregation's (or individual's) decision to adopt a text.

${ }^{22}$ The Koren Rosh Hashana Mahzor, translation and commentary by Rabbi Jonathan Sacks (Jerusalem: Koren Publishers, 2011). Some reference will also be made to The Koren Yom Kippur Mahzor, translation and commentary by Rabbi Jonathan Sacks, second ed. (Jerusalem: Koren Publishers, 2013). The one-volume 2018 Koren Mahzor Yamim Nora'im combines these two volumes but abbreviates the commentary; it has not been included here. Jonathan Sacks has published voluminously. For a relevant selection of his writings, see Jonathan Sacks: Universalizing Particularity, Hava Tirosh-Samuelson and Aaron W. Hughes, eds., (Leiden/Boston: Brill, 2013). The Sacks-Koren liturgies reverse the standard layout and place the Hebrew on the left and the English on the right of every opening, reinforcing that this is a Hebrew book that reads right to left.
} 
outer margins of the pages. ${ }^{23}$ In both these cases, the commentaries are entirely or mostly designed for individuals to access at will during the extended services of these days.

The rabbis of the Reform Movement, the liberal end of the American Jewish spectrum, published Mishkan HaNefesh in 2015. Reform liturgies have historically much abbreviated the traditional texts and freely eliminated or rewritten prayers that were found theologically problematic. This fact is still the case, but there has been a significant reassessing of tradition over the decades. Unlike its predecessors, Mishkan HaNefesh not only includes the traditional Hebrew text for our two prayers but also regularly translates it nearly literally (and consistently from one service to the next). There are some significant theological subtleties embedded in its translations, though. Usually, it places the Hebrew text, its transliteration into Latin characters, and its literal translation on the right-hand page of the opening; on the left are a variety of alternative readings or study texts that can be substituted for the literal translation..$^{24}$ Across the bottom appear further notes and comments. ${ }^{25}$

As a foil to these three, I also include in these discussions the 1985 more rightwing orthodox ArtScroll mahzor, a text that was then innovative in its graphic qualities and its inclusion of extensive English commentary. This commentary mostly collates received pre-modern interpretations of the prayers. ${ }^{26}$ Finally, I make occasional reference to the Reconstructing Movement's Kol Haneshamah series, including its 1999 Prayerbook for the Days of Awe. ${ }^{27}$ This text was the first American liberal liturgy to provide the movement's laity with commentary. However, this commentary is much more limited than more recent ones, especially on our questions.

This article focuses on the commentaries on a narrow selection of prayers, each found in all these volumes, each of which makes a statement about universalism and particularism. Two prayers come from the amidah, the central prayer of every service. The first, the three paragraphs beginning "And So" (Uv'khen) is unique to this season, introducing the "sanctification of God's Name" in the third benediction; the second, the "sanctification of the day," the fourth benediction, is recited

\footnotetext{
${ }^{23}$ Mahzor Lev Shalem for Rosh Hashanah and Yom Kippur (New York, NY: The Rabbinical Assembly, 2010). "Introduction," $x$, gives a full-page discussion of the principles used for the translation. The Lev Shalem and ArtScroll liturgies, like the majority of their predecessors, place the Hebrew text on the right-hand page and the English translation on the left.

${ }^{24}$ Unlike its immediate predecessor, the Gates of Repentance (New York: Central Conference of American Rabbis, 1978, revised 1996), which interspersed paragraphs of Hebrew and English text.

${ }^{25}$ Mishkan Hanefesh: Machzor for the Days of Awe, separate volumes for Rosh Hashanah and Yom Kippur (New York: CCAR Press, 2015). While the Gates of Repentance was published in both English and Hebrew opening formats, this text is only Hebrew opening.

${ }^{26}$ The Complete ArtScroll Machzor, Nusach Ashkenaz, translation and commentary by Rabbi Nosson Scherman, separate volumes for Rosh Hashanah and Yom Kippur (New York, NY: Mesorah Publications, 1985, rpt. 2000).

${ }^{27}$ Kol Haneshamah, Mahzor Leyamim Nora'im: Prayerbook for the Days of Awe (Elkins Park, PA: The Reconstructionist Press, 1999). "Reconstructing" replaced "Reconstructionist" in 2018 as the name of this small movement that is ideologically extremely liberal but liturgically somewhere between Conservative and Reform in practice.
} 
with small variations on all festivals. The third prayer, "It is incumbent upon us" ("Aleynu), originated for Rosh Hashanah but now concludes every single service daily. The fourth, "And they shall come" (Vaye'etayu), is an ancient hymn for this season.

While prayers from the rest of the year could also serve this study, this focused investigation of prayers from a day when our specific question of universalism and particularism comes to a head provides a targeted sample for investigating how contemporary American Jews dialogue with this theological issue.

\section{"And so"}

The Rosh Hashanah and Yom Kippur liturgies add a series of three paragraphs to the blessing about God's holiness, the "sanctification of God's Name." ${ }^{28}$ During these ten days, this blessing concludes by praising God not as the "holy God" but as the "holy Sovereign," thus introducing the themes of divine majesty and power on which these inserts elaborate. All our commentaries suggest that these inserts can be dated to the second or third century CE. Hayyim Herman Kieval claims more accurately that the origin of the prayer is obscure, though it seems to have been known by the Geonic period, i.e., the last centuries of the first millennium CE. ${ }^{29}$

The first paragraph reads as unabashedly universalist in its horizon, asking:
And So
Place fear of You, Eternal our God, on all Your doings, And terror of You on all that You have created,
And all the things You have done will be in awe of You
And all that You have created will prostrate before You;
And all of them shall be bound together to perform Your will wholeheartedly. As we have known, Eternal our God, that dominion lies before You,
Strength in Your hand, power in Your right arm,
And Your name is awed by all that You created. ${ }^{30}$

The word "all" (כל, kol) echoes here six times-asking that God create the conditions that will encourage all creation to come into relationship with God. Whether

\footnotetext{
${ }^{28}$ In public prayer, in the repetition of the amidah, the angelic liturgy precedes these inserts.

${ }^{29}$ The High Holy Days: A Commentary on the Prayerbook of Rosh Hashanah and Yom Kippur, David Golinkin and Monique Susskind Goldberg, eds. (Jerusalem: The Institute of Applied Halakhah, The Schechter Institute of Jewish Studies, 2004), 78. This prayer appears in received versions of the late ninth-century Seder Rav Amram Gaon, though not in the Siddur Rav Saadia Gaon from fifty years later. Maimonides (d. 1204) presents it as optional. More research is needed.

${ }^{30}$ This deliberately hyper-literal translation, as well as those following, is mine. "Doings" and "done" translate literally מעשים מעשיך, but these terms are poetic shorthand for "the doings (i.e., works) of creation," and the terms thus appear here as a synonym for "created" and "creations." Notice the poetically inflected elements in the doublets and frequent use of parallelism, especially in the first half. However, the absence of rhyme or any sort of meter supports a dating to the early centuries of the common era, before the appearance of these characteristics in Hebrew poetry mid-millennium.
} 
this is a pluralist vision that accepts that peoples will worship God in their own ways or an inclusivist vision that expects all to join Israel is not explicit, but nonJews, as part of all creation, will participate.

The second paragraph's focus has a particularist horizon, reading:

\author{
And So \\ Place glory, Eternal One, on Your people; praise on those in awe of You, and \\ good hope to those who seek You; and the ability to speak out to those \\ who hope for You; \\ [give] rejoicing to Your land and gladness to Your city; \\ and the sprouting of the ray of David Your servant and the arrangement of the \\ lamp of the Son of Jesse Your Messiah, speedily in our day. ${ }^{31}$
}

Its focus is eschatological, asking that God restore the people Israel and their land, bringing messianic times. It makes no mention of non-Jews.

The third elaborates on this eschatological vision:

\title{
And So
}

The righteous will see and rejoice; and the upright will be jubilant; and the pious will celebrate with song.

And injustice will clamp shut its mouth, and absolutely all evil will disappear like smoke,

For You will remove the reign of insolence from the earth.

Then You alone, O Eternal, will reign over all that You have done, on Mount Zion, the dwelling place of Your Glory, and in Jerusalem, Your holy city. As it is written in Your holy Writings, "The Eternal will reign forever, your God, oh Zion, from generation to generation, hallelujah."

In response to the advent of the eschaton, the righteous will rejoice, but the unjust, the evil ones, and insolent governments will disappear. This enables God's eternal reign from Zion. The contrast here between the three-fold iteration of rejoicing righteous, presumably but not explicitly Jews, and the threefold silencing and removal of the wicked, referred to in language that alludes to gentiles, ${ }^{32}$ reinforces the movement of this prayer to particularism, albeit less explicitly so.

\footnotetext{
${ }^{31}$ The poetic quality of this paragraph lies primarily in the superfluity of synonyms and in the conclusion of each phrase with the suffix $7^{-}(k h a$, You, Your), referring to God.

${ }^{32}$ Because Christian censors objected to this last part, it became more abstract, both in Hebrew and in translation. See, for example, Ms. Cambridge Add. 662, p. 128, http://cudl.lib.cam.ac.uk/view/MSADD-00662/128, where a censor has erased memshelet zadon ("the reign of insolence"). In the margin, a later hand has written hahot'im bezadon (those who sin arrogantly/deliberately). The term zadon appears in Ex 18:11 and Neh 9:10 referring to Pharaoh, and in Jer 50:29-32 to Babylonia, i.e., all archenemies of Israel. This term was frequently understood to apply to current governing powers.
} 
Today's interpretations of this prayer dialogue in varying ways with its particularism. The commentary in the very traditional Orthodox ArtScroll Mahzor reads the three sections as a single composition. It cites the eighteenth-century Italian rabbi, Moses Chaim Luzzato, as teaching that:

God's glory on earth is revealed through the agency of Israel, because it is the nation that received His Torah and proclaims His Unity. When Israel is exiled and degraded, it is less able to be the "chariot" of His holiness. As a result, not only Israel, but the entire world suffers. Thus we pray that God returns the glory of Israel, of the righteous, of Jerusalem... When that happens, all nations will be inspired to unite under the leadership of Israel in the service of God. [emphasis mine] ${ }^{33}$

In other words, this interpretation (and the more detailed commentary that follows) is a direct answer to "Gifts and Calling"'s vision. Like the Church's, its universalism is at best inclusivist. God's relationship with the nations depends not on proselytism, though, but on their being attracted to Israel's message, something that cannot happen fully until Israel is no longer degraded in exile. Then, in messianic times, the nations will want to serve God and to accept Israel's direction. This reading then functionally rearranges the prayer's paragraphs, making the first paragraph's universal vision dependent on the realization of the subsequent particularist prayers and the nations' subservience to Israel.

ArtScroll's comment on the first paragraph is particularly ambiguous. It understands its various terms to refer to "distinct personalities," some "high-caliber people who have perfected themselves... [and] are close to God" and others "of lesser stature... [with] many shortcomings... [who] recognize God only from afar." These groups will be bound together to create a complete society "following the lead of Israel's finest products." ${ }^{34}$ Standing alone, these may be different categories of Jews, or non-Jews joining Jews, but not non-Jews in independent relationship with God. The commentary on the second paragraph refers back to this as "universal recognition of [God's] greatness," but the comment directly on the first paragraph raises the possibility that this "universality" might refer simply to universality among all types of Jews. ${ }^{35}$ This would be consistent with standard rabbinic usage, where the Talmud refers over seven hundred times to "all the world" (kulei 'alma'), usually meaning just the rabbinic elite.

Orthodox rabbi Jonathan Sacks does not close off the universal horizon. In commenting on the first reference to all creation (paragraph one), he points specifically to the universal nature of Rosh Hashanah's themes, referring not just to Jews

\footnotetext{
${ }^{33}$ Complete ArtScroll Mahzor, Rosh Hashanah (1985), 64. This text also ascribes these prayers to Rav, an early third century rabbi. Compare this to the commentary on the third paragraph in The Metzudah Machzor (New York, NY: Metzudah Publications), quoting indirectly from Yehuda Halevi's Kuzari, which remains exclusivist. See: https://www.sefaria.org/Machzor_Rosh_Hashanah_Ashkenaz Linear\%2C_Maariv\%2C_Amidah?lang=en, n. 47.

${ }^{34}$ Complete ArtScroll Mahzor, Rosh Hashanah (1985), 64-65.

${ }^{35}$ Complete ArtScroll Mahzor, Rosh Hashanah (1985), 65.
} 
but to all humanity. This, he says, is because Rosh Hashanah is the anniversary of creation and God's creation of all humans. Thus, he says, "The God of Israel is the God of all," and God judges all humans on this day. ${ }^{36}$ Sacks also offers an interpretation of the three passages as a unit, drawing attention to their movement "from the universal to the particular." He comments somewhat polemically, "This direction, beginning with the universal and progressively narrowing the focus to the particular, is characteristic of Jewish thought." After examples of this from Torah and liturgy, he asserts, "This is the opposite of the Greek way of thinking, that of Plato especially, which moves from the particular to the universal. In Judaism, what is precious to God is our particularity, our uniqueness." ${ }^{37}$ Thus, he leaves us with a tension. Although the themes of the day are universal, Judaism naturally and justifiably tends to the particular. He blends universal and particular as descriptors of communal horizons and a contrast between inferential and deductive logic.

The Conservative Movement's Mahzor Lev Shalem offers historical and philological comments in its right-hand margin of the opening - here pointing to the sequence of ideas between the three passages from universal to particular and the prayer's purportedly early origins. Readings in the left-hand margin seek to inspire. On this prayer, it offers two somewhat inconsistent readings. The first, a quote adapted from Martin Buber, titled "May All be Bound Together," comments on the prayer's opening paragraph, reading:

The purpose of creation is not division, nor separation. The purpose of the human race is not a struggle to the death between classes, between nations. Humanity is meant to become a single body...Our purpose is the great upbuilding of unity and peace. And when all nations are bound together in one association living in justice and righteousness, they atone for each other. ${ }^{38}$

This emphasis on human unity for the sake of building a just and peaceful society raises only the prayer's universalist message, submerging its particularist voices. The focus on all humanity suggests a universal horizon, but the passage makes no mention of Jews or non-Jews.

\footnotetext{
${ }^{36}$ Alluded to liturgically especially in the response to the three sets of shofar blasts during the additional (musaf) service: "This day is the birthday of the world; this day causes all creatures of the world(s) to stand in judgement, whether like children or like servants..." (Sacks-Koren, Rosh Hashana, 606 et al.) The theme of universal judgement also occurs in the poem Un'taneh Toqef, elaborating on the pastoral image of Mishnah Rosh Hashanah 1:2, "On Rosh Hashanah all who have come into the world pass before God like sheep" (Sacks-Koren, Rosh Hashana, 566-68 et al.).

${ }^{37}$ Sacks-Koren, Rosh Hashana, 70-73; cf. 384-387, where he points explicitly to the reiterations of "all," and 518. He has little comment on this on Yom Kippur except for a repetition of these ideas during the evening service.

${ }^{38}$ Mahzor Lev Shalem, 13 (RH evening), 189 (RH afternoon), 215 (YK evening), 377 (Yom Kippur afternoon). The evening services also serve as the text for the personal recitation of this prayer in the morning. Adapted from Buber's Israel and the World: Essays in a Time of Crisis, (New York, NY: Schocken Books, 1948), 186, where Buber does indeed allude to this prayer.
} 
However, for the repetition of this prayer in the morning on Rosh Hashanah, Mahzor Lev Shalem offers an inspirational text from Heschel instead, one that does address the question of Jews and non-Jews:

...Is religious uniformity desirable or even possible?...Does not the task of preparing the Kingdom of God require a diversity of talents, a variety of rituals, soul-searching as well as opposition? Perhaps it is the will of God that in this eon there should be diversity in our forms of devotion and commitment to God. ${ }^{39}$

Heschel's quotation thus challenges any vision that, in the eschaton, all humanity should become Jews or under Jewish leadership. This vision is neither particularist nor universalist but rather pluralist. This not so subtly contradicts Buber's view of unity and even the trajectory of the prayer itself.

The Reform Movement's mahzor, Mishkan HaNefesh, offers a wide variety of interpretative materials, through translations, alternative prayer texts, study materials, direct commentaries, and introductory essays, that cumulatively seek to reinterpret particularism in favor of universal understandings. In an introductory essay, Lawrence Hoffman points to the various innovations in this mahzor that deliberately emphasize universalism, continuing a trend characteristic of American Reform liturgies. This prayer, he says, "anticipates a world where 'good people everywhere will celebrate' a time when 'evil has no voice, and the rule of malevolence fades like wisps of smoke." $40 \mathrm{He}$ thus interprets the somewhat ambiguous language of the prayer's third paragraph as expressing a universal eschatological vision. He ignores the particularism of the second paragraph entirely. He concludes, citing Edmund Fleg: "The promise of Judaism is a universal promise."

The commentaries accompanying the prayer reflect this emphasis. A full-page study text preceding the prayer acknowledges the tension created by reading the third paragraph as universal. ${ }^{42}$ It asserts that these passages collectively "describe a world suffused with the holiness of God." The first paragraph states that "all creation is united by a sense of AWE and reverence for the Divine." "Awe" is this paragraph's heading; the translation virtually erases the language of "fear of God" in favor of awe, reading, "...give all creation the gift of awe. Turn our fear to reverence; let us be witnesses of wonder..." 43 The second paragraph then addresses

\footnotetext{
${ }^{39}$ Mahzor Lev Shalem, 87. Titled Many Faiths, One God, i.e., not words from this prayer. Excerpted from "No Religion is an Island," in Moral Grandeur and Spiritual Audacity, Susannah Heschel, ed. (New York, NY: Farrar, Straus, and Giroux, 1996), 243-244.

${ }^{40}$ Rabbi Lawrence A. Hoffman, "Universalism in Mishkan HaNefesh," Mishkan HaNefesh, Rosh Hashanah, xxviii.

${ }^{41}$ Hoffman, xxix. He identifies Fleg (1874-1963) as a French intellectual. These words explain why he reclaimed his previously rejected Jewish heritage. No source cited.

${ }^{42}$ Rosh Hashanah, in the evening (48) and morning (183) services, and Yom Kippur evening (52).

${ }^{43}$ This continues the precedent set by this book's predecessors for this paragraph. Compare, on this, the downplaying of "fear" in Mahzor Lev Shalem and in the Reconstructing Kol Haneshamah, 111 (this prayer also appears in each service). The latter translates the various Hebrew terms for fear as awe, knowledge, and worship.
} 
Israel's need to receive "HONOR and respect," precisely because of its historical reality as a "vulnerable and often despised" people. ${ }^{44}$ The third paragraph addresses abstract moral values, as "evil has been vanquished by RIGHTEOUSNESS." Each paragraph receives the header, "How Do We Sense God's Holiness? Through AWE/HONOR/RIGHTEOUSNESS," respectively, with the capitalized word epitomizing the paragraph's theme.

The introductory paragraph continues:

Together, these three prayers set forth a vision of a world in which God's presence is felt and experienced everywhere. We sanctify God, therefore, ...by realizing that vision through our actions: showing reverence for all creation, giving kavod [honor] to all people - especially those who are vulnerable and needy-and embodying righteousness in all that we do.

Honor, then, is not something that Israel, in particular, just receives; it is something that humans universally, among them Israel, give to the world. Israel's past suffering, then, does not generate a particularistic prayer but instead becomes a motivation for a universally oriented ethic.

The editors of this volume still struggle with the non-universal elements of the second and third paragraphs. Mishkan HaNefesh restores the original Hebrew messianic conclusion to the second paragraph. ${ }^{45}$ Its predecessor, the 1978 Gates of Repentance, attempted to balance the paragraph's allusions to Israel and Jerusalem by concluding "and cause the light of redemption to dawn for all who dwell on earth" [emphasis mine]. ${ }^{46}$ Mishkan HaNefesh still does not translate the last two phrases literally, writing instead, "May the sparks of David, Your servant, soon grow bright enough for us to see a beam of light in the darkness, a promise of perfection. ${ }^{" 47}$ Its comment apologetically explains the reintroduced reference to the Davidic messiah, admitting that it contradicts the conventional Reform Jewish "vision of a messianic age, created by human acts of tikkun olam (repairing the

\footnotetext{
${ }^{44}$ A variation on this comment appears in the notes to this second paragraph, Mishkan HaNefesh, Rosh Hashanah, 50, "The Gift of Honor." See also the alternative readings, p. 189, "Honor for Israel: The Dream of Kavod" and "The Right to be Different." These passages, and a note "The gift of honor" (Yom Kippur, 224) all express the Jewish desire for normalcy as a nation among nations.

${ }^{45}$ Kol Haneshamah, 111-112, etc., omits this, and explains the omission here and on 746 (Yom Kippur): "Most Jews of the modern era do not expect or desire a divinely appointed royal personage to come and solve our problems for us...but in rejecting the literal Messiah we do not have to abandon the messianic passion... We need to take responsibility for bringing messianic days by enthusiastically advancing the ideals of human freedom, dignity, and creativity" (Seth D. Riemer, for this volume).

וצמיחת קרן לכל יושבי תבל 46 , 32, 112, 317 (i.e., the more literal translations). Compare The Union Prayerbook for Jewish Worship II, Newly Revised Edition (Cincinnati, OH: Central Conference of American Rabbis, 1945), 20-21 et al., which removes all explicit allusions to Israel and Jerusalem in all its services, including fully universalizing this passage. Mishkan HaNefesh has also restored, without comment, the Hebrew and English references to God's reigning over all creation from Zion and Jerusalem in the next blessing of the amidah. On Yom Kippur, alternative readings for this paragraph include several modern poems about Jerusalem $(59,229)$. Indeed, the explicit Zionism of this tome is remarkable considering the contemporary discomfort of many Reform laity with the current state.

${ }^{47}$ Mishkan HaNefesh, Rosh Hashanah 50, 185, Yom Kippur, 54, 224, 374.
} 
world)" - rather than one initiated supernaturally by a human Messiah. David thus appears here "not as the literal progenitor of the Messiah, but as an emblematic figure who shines through Jewish history as a symbol of messianic hope." ${ }^{48}$ Perhaps the interpretative translation offered here begins to resolve this tension.

The translation of the third paragraph refers explicitly to "good people everywhere" and reorganizes the prayer's phrases, thus removing any possibility of constructing a good versus evil, particularist dichotomy. The commentaries emphasize that Judaism embeds within it just such an eschatological optimism about the possibilities of a transformed society in which conflict can be resolved without violence, achieving the prophetic vision of "a messianic age in which Jerusalem becomes a spiritual center with a kind of World Court for the peaceful adjudication of disputes." ${ }^{49}$ The message of this prayer book includes positive portrayals of nonJews, including a prayer for righteous gentiles, printed as an alternative reading for the end of this third paragraph. ${ }^{50}$

Thus, to different degrees, our primary commentaries all value universalism, but their community's theological strategies and liturgical options shape their possibilities for addressing the particularistic voices in this prayer. Orthodox Jews pray only by the received Hebrew text. New ideas thus find expression through commentaries, but even then, received interpretations carry weight. The new Conservative liturgy also maintains traditional texts, especially for this season, but also turns in the margins to leading twentieth-century thinkers to trigger challenges to some traditional meanings. Reform Jews can and do change texts, although, in recent decades, they have also retrieved traditions earlier abandoned. Due to intermarriage, their communities also embrace the largest number of non-Jews. Theological struggles are embedded in the volume itself; it invites congregants to engage them. ${ }^{51}$

\section{You have chosen us...}

Other prayers confirm these observations. The "sanctification of the day" follows immediately in the amidah. It is common to all festivals, with adaptations specific to the day. The Rosh Hashanah version especially contains a similar set of tensions between the universal and particular. As on all festivals, the prayer opens with an unabashedly particularist statement, describing God's choice of Israel from among all peoples.

\footnotetext{
${ }^{48}$ Mishkan HaNefesh, Rosh Hashanah, 50; Yom Kippur, 54. Compare Yom Kippur, 224 which stresses the "sprouting" as an image of gradual, organic growth.

${ }^{49}$ Mishkan HaNefesh, Yom Kippur, 56. This long reading dialogues with an implicitly Christian understanding of inherently flawed human nature, pointing to the Jewish teaching that while people do have destructive tendencies, they also have "a moral instinct that controls and channels our harmful drives, gives rise to generous and cooperative acts, and inspires us to work for a better world." Compare Rosh Hashanah, 51.

${ }^{50}$ Mishkan HaNefesh, Yom Kippur, 227.

${ }^{51}$ On the dynamics shaping how different Jewish communities respond to historical and theological change, see my "Liturgy in the Light of Jewish-Christian Dialogue," Studies in Christian-Jewish Relations 4 (2009), https://ejournals.bc.edu/index.php/scjr/article/view/1541/1395.
} 
You have chosen us from all the peoples; You have loved us and desired us and elevated us beyond all other tongues and sanctified us with Your commandments and drawn us near to Your worship; and by Your great and holy Name You have called us. And You have given us [language describing the specific festival].

Following a standard petition that God remember Israel on this day, the Rosh Hashanah version of this prayer switches to the universal, asking God to be manifest to all creation. Again, we see the reiteration of the Hebrew kol (כל, "all" and synonyms, italicized in the translation):

Our God and God of our ancestors, reign over the entirety of the whole world in Your glory, and be lifted above all the earth in Your grandeur.

And appear in the majesty of the splendor of Your power over all those who dwell on earth, Your land.

Then every being will know that You animated it, and every creature will know that You created it.

And everyone with breath in his [/her] nostrils will say: The Eternal, the God of Israel is Sovereign, and His sovereignty is over all dominion. ${ }^{52}$

The prayer then concludes with a return to particularist prayers for Israel's own needs. The universalist/particularist tensions thus are explicit within the prayer. The evidence from the commentaries is consistent with what we learned above.

ArtScroll begins by asserting that Rosh Hashanah's theme of God's kingship includes "the expectation that all humanity will recognize him ultimately." Chosenness means that we must repent and live up to the "heavy responsibilities inherent in that calling." It then goes on to say that "God chose us because He found Israel to be superior to the other nations." ${ }^{53}$ As we saw above, this fairly right-wing orthodox commentary is not in dialogue with non-Jews. ${ }^{54}$

By contrast, Jonathan Sacks has no comment on this prayer on Rosh Hashanah or Yom Kippur. In his volume for the rest of the year, his sole comment historicizes chosenness. The prayer, he says, references "the Divine choice of Israel as the people who, through their singular history, bear witness to the role of God in history." He thus chooses not to engage our issues here.

The Conservative mahzor offers two interpretative apologies for any possible sense of superiority. The first by Rabbi David Wolpe (b. 1958) asserts that "To be chosen is not to be better than others." That is the response of the persecuted, "disfigured by the ugliness of history." Nor is chosenness to claim some exclusive relationship with God. Instead, it points to the Jewish mission to change the world,

\footnotetext{
${ }^{52}$ On Yom Kippur, this paragraph prays for forgiveness of sin. On festivals, it prays in general terms for the day's proper celebration. In the additional service on all days, the entire prayer is different; it addresses the day's sacrifices and the lack thereof today.

${ }^{53}$ Complete ArtScroll Machzor, Rosh Hashanah, 68.

${ }^{54}$ Citing the Belzer rebbe, Shalom Rokeach, 1780-1846, Polish Galicia.

${ }^{55}$ Jonathan Sacks, The Koren Siddur (Jerusalem: Koren Publishers, 2009), 774 and 777.
} 
to improve it. ${ }^{56}$ Like Sacks, the second reading, by the Holocaust survivor Rabbi Leo Baeck, seeks to historicize chosenness and thus remove its contemporary significance. Today, he says, the onus is on Israel to be free people, not slaves, and to accept its own task.$^{57}$ Thus the editors of this mahzor, while not free to change the Hebrew prayer's wording, and bound to literal translations by the norms of the volume itself, seek to mitigate the particularism of the prayer by denying the legitimacy of any literal understanding of its language.

This only becomes more extreme in the Reform Movement's mahzor. The study passages introducing the Rosh Hashanah volume teach that Judaism is a "global religion" because its calendar numbers years not according to a Jewish event, but from "the birth of the universe and the birth of [all] humanity...in God's image." 58 In other words, while Christians and Muslims live by very particularist calendars, Jews are, in this sense, universalists! The translation of this prayer still acknowledges chosenness, but adds a statement of its purpose, beginning "You chose us, with love, to be messengers of mitzvot," thus transforming God's commandments (mitzvot) from a mark of favoritism to a statement of mission. Rather than God's calling Israel by the Divine name - Yis-ra-EL means "he who strives with God" 59 - God's name here "has become our calling."60

Throughout the two volumes of this mahzor, no fewer than six different footnotes address the theme of chosenness in this prayer ${ }^{61}$ in addition to several alternative readings or study texts. Notable is the insistence over and over that Israel has no special status before God, that Jews have no "biological or racial superiority" because "Jews belong to all races, and welcome as converts people of all races, ethnic groups, and nations." ${ }^{2}$ While not exclusively true for Reform communities, this is particularly characteristic of them, especially with the turn to deliberate "Outreach" in recent decades. ${ }^{63}$ At least once each day, this mahzor quotes Amos 9:7, "To Me, O Israelites, you are just like the Ethiopians-declares Adonai. True, I brought Israel up from the land of Egypt, but also the Philistines from Caphtor and the Arameans from Kir." In other words, the Israelites are just

\footnotetext{
${ }^{56}$ Mahzor Lev Shalem, 14, adapted from Why Be Jewish? (New York, NY: Henry Holt \& Co, 1995), 38-40. Note that the excerpt omits Wolpe's specific mention of Christianity, and stops short of his declaration, "So Jewish chosenness was actually less exclusive than the chosenness characteristic of many other peoples and faiths."

${ }^{57}$ Mahzor Lev Shalem, 88, 216, citing from Baeck's This People Israel: The Meaning of the Jewish Experience, Albert H. Friedlander, trans. (Philadelphia, PA: The Jewish Publication Society of America, 1964), 402-403, from the concluding, forward-looking pages of the book.

${ }^{58}$ Mishkan HaNefesh, Rosh Hashanah, 4, adapted from Rabbi Harold Schulweis, "Jewish World Watch Founding Sermon," Jewish World Watch (Rosh Hashanah, 2004), available at http://web.archive.org/web/20131127202542/http://www.jewishworldwatch.org/aboutjww/sermon.html.

${ }^{59}$ See the ArtScroll Machzor and Mahzor Lev Hadash.

${ }^{60}$ Mishkan HaNefesh, Rosh Hashanah, 53, 194, 317; Yom Kippur 60, 230, 382, 636.

${ }^{61}$ Mishkan HaNefesh, Rosh Hashanah, 53, 194; Yom Kippur 60 (two), 61 (alternate reading and comment on it), 382.

${ }^{62}$ Mishkan HaNefesh, Yom Kippur alternative reading, 61.

63 "Outreach," Union for Reform Judaism, https://urj.org/what-we-believe/resolutions/outreach.
} 
like other nations. ${ }^{64}$ As evidenced by prophetic critiques, chosenness also does not "imply moral superiority." It does, though, confer special responsibility to strive for moral excellence. ${ }^{65}$ The Reform Movement, we are told, understands chosenness "in the sense that we are chosen for a special mission, to be a witness to the reality and oneness of God...[This] does not deny that God may well have chosen other peoples for other sorts of missions in the world." ${ }^{66}$

The most extreme answer to the challenge posed to contemporary Jews by the liturgical language of chosenness is that of Reconstructing Judaism. Its founder, Rabbi Mordecai M. Kaplan, considered the concept itself untenable and inconsistent with a naturalistic conception of God. ${ }^{67}$ Therefore, he excised it from the movement's original 1945 prayer book. ${ }^{68}$ As Eric Caplan writes, "Kol Haneshamah perpetuates Kaplan's rejection, on moral terms, of the concept of chosenness," understanding that it "always implies unacceptable favoritism." ${ }^{69}$ In this mahzor, the tension between universalism and particularism characteristic of the two prayers we have examined is much diminished in favor of universalism.

\section{'Aleynu}

Poetic texts associated with this season also address similar themes. The most prominent of these is known by its first Hebrew word, 'aleynu (it is incumbent upon us). Originally a poetic introduction to the shofar (ram's horn) blasts on Rosh Hashanah, emphasizing the theme of divine majesty, it began to conclude every service year-round in the twelfth century. Its first paragraph highlights Jewish particularity, including describing God "Who has neither made us like the nations of the lands nor placed us like the families of the earth,/ Who has not made our share like theirs, nor our fate like that of their multitudes." The second paragraph looks eschatologically to when all nations will join in worship of God.

As Sacks describes it, these two paragraphs contrast "present reality with future hope: (1) the reality that Jews are different in holding God as their only King, the only nation in the world constituted by a religious belief; and (2) the hope... that one day, all humanity will recognize the One God as their King." ${ }^{, 70}$ When contrasting the particularist horizon of the first paragraph with the universalism of the

\footnotetext{
${ }^{64}$ Mishkan HaNefesh, Yom Kippur, 61; Rosh Hashanah, 53 (comment adapted from Reuven Hammer, Or Hadash: A Commentary on Siddur Sim Shalom (New York: The Rabbinical Assembly, United Synagogue of Conservative Judaism, 2003), 125.

${ }^{65}$ Mishkan HaNefesh, Yom Kippur, 61.

${ }^{66}$ Mishkan HaNefesh, Rosh Hashanah, 194, adapted from the "Commentary on the Principles for Reform Judaism," (October 27, 2004), III, available at https://web.archive.org/web/20121109171647/http://www.ccarnet.org/rabbis-speak/platforms/commentary-principles-reform-judaism/.

${ }^{67}$ Eric Caplan, From Ideology to Liturgy: Reconstructionist Worship and American Liberal Judaism (Cincinnati, OH: Hebrew Union College Press, 2002), 30.

${ }^{68}$ Caplan, 64-68.

${ }^{69}$ Caplan, 192.

${ }^{70}$ Sacks-Koren, Rosh Hashana, 524-525, the first iteration of the prayer in its original location. He does not make similar observations with other occurrences of the prayer.
} 
second, he concludes, consistent with his comment cited above, "There is no contradiction between particularity and universality. Only by being what we uniquely are, do we contribute to humanity as a whole what only we can give." 71 ArtScroll, too preserves Jewish distinctiveness; universal worship of God by non-Jews will be as Noahides, not as Jews. ${ }^{72}$

Mahzor Lev Shalem preserves the traditional text of this prayer, ${ }^{73}$ never commenting on the particularist themes of its first paragraph or the hopes for the downfall of idolatry that introduce the second, thus dodging the dynamic of interest here. It focuses instead on the positive hopes expressed, interpreted from the nineteenth century on as being a call for "universal justice" and "to be partners with God in achieving a time of peace and righteousness." ${ }^{.74}$ This casts the second paragraph's statement more as inclusivist than universalist.

Liberal Jews early rejected the prayer's particularist elements. Kaplan fundamentally rewrote this prayer for Reconstructionists. Reform Jews, in their earlier American liturgies, revised it to eliminate its comparisons between Jews and nonJews. ${ }^{75}$ These versions (and more) still appear as alternative readings. Even today's "literal translation" blurs the particularism of the original Hebrew, reading "who made us unique in the human family, with a destiny all our own." 76

\section{Vaye'etayu}

A final example comes from an anonymous ancient hymn, ${ }^{77}$ known by its first word, ("and they shall come"), recited on both Rosh Hashanah and Yom Kippur. ${ }^{78}$

\footnotetext{
${ }^{71}$ Sacks-Koren, Rosh Hashana, 36-38 (afternoon service preceding the holy day). Compare The Koren Siddur, 182-184.

${ }^{72}$ Nosson Scherman, The Complete ArtScroll Siddur (New York: Mesorah Publications, Ltd., 1984), 158-159, citing Samson Raphael Hirsch. No commentary appears in the ArtScroll mahzor. Rabbinic tradition early understood that God judged the righteousness of non-Jews by their adherence to the seven commandments given to Adam and Noah. See David Novak, The Image of the Non-Jew in Judaism: The Idea of Noahide Law, second ed., Matthew Lagrone, ed. (Portland OR: The Littman Library of Jewish Civilization, 2011).

${ }^{73}$ Unlike the orthodox liturgies, though, it does not restore its censored line. On the history and censorship of this prayer, see my "The Censorship of Aleinu in Ashkenaz and Its Aftermath," in The Experience of Jewish Liturgy: Studies Dedicated to Menahem Schmelzer, Debra Reed Blank, ed. (Leiden: Brill, 2011), 147-166.

${ }^{74}$ Mahzor Lev Shalem, 25, 173, 246. Compare 131, 156. 325 offers, as an inspirational reading, a text by Solomon Schechter (source not identified), that suggests that this prayer contrasts God's sovereignty with that of Rome, identified classically as Esau, the prototypical enemy of Israel. The prayer's message is "that the messianic age can be recognized when an end is brought to the rule of wickedness." Siddur Lev Shalem (New York, NY: The Rabbinical Assembly, 2016), 56, 231, points to the Israeli movement's replacement of the first paragraph's statement of Jewish "exceptionalism." See also its apologia, p. 205, "Aleinu both asserts a pride in Jewish destiny and challenges us to go out to the world committed to Jewish spiritual values."

${ }^{75}$ Caplan summarizes the Reform liturgies as well. See his index.

${ }^{76}$ Mishkan HaNefesh, Rosh Hashanah, 82, 202, 288; Yom Kippur, 116, 432.

${ }^{77}$ Its poetics suggest that it is pre-fifth century CE. It embeds an alphabetical acrostic as the third letter of each stich, most stichs are three words long, but it has neither meter nor rhyme.

${ }^{78}$ Traditionally inserted into the third paragraph of "And So" in the repetition of musaf, the additional service.
} 
As the commentaries point out, the poem describes with gusto an eschatological vision of the nations' casting off their idolatrous practices and coming to worship God. ${ }^{79}$ Thus, while its horizon is universal, it is not a pluralist acceptance of the nations in their own religious integrity. The twelfth stich asserts that "they will teach the errant wisdom." Thus, this poem reinforces the particularist reading of the final "And So" paragraph.

This poem's modern impact was heightened for the English-speaking world by Israel Zangwill's interpretative translation, "All the World Shall Come to Serve Thee," first published in 1904 for a new British orthodox prayer book, ${ }^{80}$ and subsequently set to music at least twice. ${ }^{81}$ A version of Zangwill's text entered the 1945 "newly revised edition" of the Reform High Holy Day liturgy. ${ }^{82}$ The lively 1932 setting by A.W. Binder was regularly sung year-round in my childhood at Rodef Shalom Congregation in Pittsburgh. ${ }^{83}$

Mishkan HaNefesh breaks new ground, though. It offers only the first verse in Hebrew, accompanied by "a contemporary [English] version," no less universal in horizon, beginning "May all be moved to serve You." While those writing this version apparently paraphrased Zangwill and wrote to fit Binder's musical setting, they removed all reference to idolatry. The closest they come is, "When we speak about Your glory, / when we praise You for Your might - / those who hear will feel Your presence, / turn from darkness to the light." 84

Zangwill's translation also entered Conservative liturgies, but with different adjustments. The mahzor commissioned by the Rabbinical Assembly, published by Ben Zion Bokser in 1959, notes that it follows a different version of the Hebrew and has adjusted the translation. In reality, this new translation goes well beyond the Hebrew's textual changes. Where Zangwill translated a stich no longer in Bokser's version, “And their graven gods shall shame them," Bokser fills the space

\footnotetext{
${ }^{79}$ See the Complete ArtScroll Machzor, Rosh Hashanah, 495-6, 550; Yom Kippur, 544. Sacks-Koren, Rosh Hashana, 586-587, 826-827, does not comment directly on the poem, but provides this information before it. He repeats this instruction on Yom Kippur, 864-865 and adds in a comment that this is "a poetic expression of the prophetic faith that one day all nations will recognize the sovereignty of God..." Mahzor Lev Shalem, 150, 322, has a more extensive discussion about the hymn's interpretation in its right margin.

${ }^{80}$ Service of the Synagogue: A New Edition of the Festival Prayers..., authorized by Chief Rabbi Hermann Adler (London: George Routledge and Sons, 1904; third edition 1911), Day of Atonement, Part II, 154-155; cf. New Year (1906), 151-152.

${ }^{81}$ See the Union Hymnal for Jewish Worship (n.p.: Central Conference of American Rabbis, 1914), \#150 with a setting by Leon M. Kramer; and the Union Hymnal: Songs and Prayers for Jewish Worship, revised and enlarged third ed., (n.p.: Central Conference of American Rabbis, 1932, rpt. 1936), \#63, pp. 64-65, with a setting new in this volume by A.W. Binder (both available in the Internet Archive). The first edition, from 1892, did not include this text. The third verse seems to have been omitted for reasons of length. It speaks only of the nations' praise of God. The only other substantive change is that Zangwill's "And impart their understanding to those astray at night" has become "And impart Thy understanding...," i.e., God will be the pedagogue, not the converted nations.

${ }^{82}$ The Union Prayerbook II, 92, as the concluding hymn on Rosh Hashanah morning, and in the Yom Kippur afternoon service, 275.

${ }^{83}$ Personal recollection, confirmed by Dr. Rabbi Walter Jacob. With updated English, it appears in the Yom Kippur afternoon service of the Gates of Repentance, 447-49.

${ }^{84}$ Mishkan HaNefesh, Rosh Hashanah, 201.
} 
with, "And their hands shall clasp in friendship," ${ }^{\prime 5}$ introducing a new idea. Where Zangwill concluded this stanza, "And impart their understanding to those astray in night," Bokser writes "They shall walk in understanding, who are astray in night," toning down the message. ${ }^{86}$ This is the version that appears in the left "inspirational" margin of Mahzor Lev Shalem. ${ }^{87}$

\section{Conclusion}

"Gifts and Calling" challenges the Jewish community, saying "Jews could with regard to the Abrahamic covenant arrive at the insight that Israel without the Church would be in danger of remaining too particularist and of failing to grasp the universality of its experience of God." Central prayers in the High Holy Day liturgy hold universalism and particularism in significant tension in their traditional texts. However, analysis of the contemporary commentaries published with these prayers suggests that modernity itself, not the Church or any understanding of the Abrahamic covenant, has led all but the most traditional of Jews to struggle with these prayers' expressions of particularism and to lift up their tradition's universalist and pluralist understandings of God's relationship with the world.

Christians were the liturgical others for many, albeit not all, Jews for most of two millennia. However, explicit references to Christians and Christianity are rare in Jewish liturgy, mostly because early modern Christian censorship systematically removed them. ${ }^{88}$ The experiences of persecution and marginalization experienced by Jews in both Christian and Muslim societies led to a liturgy that was indeed characterized by a particularist understanding of the current situation that did not show concern for the wellbeing of their neighbors. Still, sometimes this was also set within a universalist eschatological horizon. There is no Jewish liturgical tradition of positive responses specifically to Christianity, and traditional, received prayers are the core of the liturgy, even in liberal settings. Even were liberal Jews to theologize liturgically about Christians, the resultant statements would likely be more broadly universal, looking to all humanity.

While all the primary texts considered here preserve the traditional Hebrew texts of the prayers, all but the most right-wing orthodox have shifted their stress consistently towards a universalist horizon, one that holds a place for all humanity. The further to the liberal end of the contemporary Jewish spectrum we move, the more this affects the ideas expressed explicitly in revised prayer texts, their translations, or in interpretative translations of received texts. Why? For more liberal Jews, integration into the western world, including by marriage, certainly plays a

\footnotetext{
${ }^{85}$ The corrupted traditional version of the text makes three references to the nations' idolatry, doubling a letter of the acrostic; the manuscript version Bokser follows has only two.

${ }^{86}$ Other changes are more cosmetic. See The High Holyday Prayer Book: Rosh Hashanah and Yom Kippur, Ben Zion Bokser, trans. (New York, NY: Hebrew Publishing Company, 1959), 194-195, 408409.

${ }^{87}$ Mahzor Lev Shalem, 150, 322. The reference in this volume mistakenly states that this is Zangwill's original version.

${ }^{88}$ For detailed studies of two prayers, see my Cursing the Christians? A History of the Birkat HaMinim (Oxford, 2012); and "The Censorship of Aleinu..."
} 
role. Unmitigated particularism, while not abandoned across the board, is no longer so comfortable. But this is not directly a response to Christian universalism, to joining in the understanding that it is our Abrahamic calling to spread God's word. As frequent objects of evangelization, as a community until recently punished if it accepted converts, Jews tend to avoid expressing this sort of sense of mission. At most, Judaism teaches that one should be a "light to the nations" (Isa 42:6, 49:6), setting an example. The prayers' universal horizon does traditionally expect a universal turning to God, but as a reality divinely, not humanly, set in motion. In this, then, echoing Sacks, we can say that much of contemporary (North American) Judaism values its particularist horizons, including for its universalist purposes. 